\title{
Allylic and benzylic oxidation reactions with sodium chlorite
}

\author{
Samuel M. Silvestre and Jorge A. R. Salvador* \\ Laboratório de Química Farmacêutica, Faculdade de Farmácia, Universidade de Coimbra, Rua do Norte, \\ 3000-295 Coimbra, Portugal
}

Received 31 October 2006; revised 29 December 2006; accepted 8 January 2007

Available online 12 January 2007

\begin{abstract}
Various allylic and benzylic substrates were selectively oxidized to the corresponding enones in good yields using sodium chlorite, either in combination with tert-butyl hydroperoxide in stoichiometric conditions, or associated with $N$-hydroxyphthalimide as catalyst. These oxidation reactions were effectively and economically performed under mild, transition-metal free conditions and therefore the dual challenge of cost effectiveness and benign nature of the processes was met with.
\end{abstract}

(C) 2007 Elsevier Ltd. All rights reserved.

\section{Introduction}

Allylic and benzylic oxidations are industrially important synthetic processes due to their wide variety of applications in the synthesis of pharmaceuticals and fine chemicals. ${ }^{1}$

Relevant examples are the oxidation of $\Delta^{5}$-steroids to the corresponding biologically interesting $\Delta^{5}$-7-ketone derivatives $^{2}$ and the benzylic oxidation of xanthene to xanthone. ${ }^{3}$

Traditionally, chromium(VI)-based reagents such as $\mathrm{CrO}_{3}-$ pyridine complex, ${ }^{4} \mathrm{CrO}_{3}$ and 3,5-dimethylpyrazole, ${ }^{5}$ pyridinium chlorochromate (PCC), ${ }^{6}$ pyridinium dichromate (PDC), ${ }^{7}$ PDC-tert-butyl hydroperoxide,${ }^{8}$ sodium chromate, ${ }^{9}$ sodium dichromate in acetic acid, ${ }^{10}$ pyridinium fluorochromate, ${ }^{11} 3,5$-dimethylpyrazolium fluorochromate (VI) ${ }^{12}$ and a combination of an $N$-hydroxydicarboxylic acid imide with a chromium containing oxidant ${ }^{13}$ have been used to perform these oxidations. However, the use of large excess quantities of both reagents and volume of solvent in most of these procedures, along with the difficult work-up of the environmentally hazardous chromium residues makes such procedures inconvenient on a commercial scale.

Other classical, stoichiometric oxidative processes involve the use of manganese dioxide, potassium permanganate or selenium dioxide. ${ }^{14}$

A variety of catalytic methods for allylic and benzylic oxidations have been reported and generally peroxide-based

Keywords: Sodium chlorite; Allylic oxidation; Benzylic oxidation; Transition-metal free.

* Corresponding author. Tel.: +351 239859950; fax: +351 239827126; e-mail: salvador@ci.uc.pt oxidants have been the reagents of choice. Despite the fact that alkyl hydroperoxides are the most used peroxides in these reactions, the use of hydrogen peroxide associated with metal catalysts was also reported. ${ }^{15}$ Due to its importance, it is also worth to mention the use of molecular oxygen, combined with transition-metal catalysts, ${ }^{16}$ to perform these oxidation reactions.

Of particular environmental and economical interest is the use of tert-butyl hydroperoxide combined with different types of metal catalysts. ${ }^{17}$ Despite the good yields reported with $\mathrm{CrO}_{3},{ }^{18}$ 2,4-dimethylpentane-2,4-diol cyclic chromate, ${ }^{19} \mathrm{PDC},{ }^{20} \mathrm{Cr}(\mathrm{CO})_{6},{ }^{21} \mathrm{RuCl}_{2}\left(\mathrm{PPh}_{3}\right)_{3}{ }^{22}$ and $\mathrm{RuCl}_{3},{ }^{23}$ the toxicity of these chromium compounds and the high cost of the ruthenium catalysts motivated the search for cheaper and more environmentally acceptable methods based on the use of copper ${ }^{24}$ and cobalt ${ }^{25}$ catalysts. Recently, the use of other metal catalysts such as dirhodium(II) caprolactamate, ${ }^{26}$ manganese(II) complexes ${ }^{27}$ and manganese(III) acetate $^{28}$ in combination with tert-butyl hydroperoxide has also been reported.

A common difficulty associated with the homogeneous procedures reported so far is the separation step required for the removal of the catalysts, which cannot be easily recovered and reused.

The immobilization of inorganic reagents and catalysts useful in organic reactions on heterogeneous supports is a very important area in clean technology ${ }^{29}$ and led researchers to report the use of chromium-based heterogeneous catalysts in combination with tert-butyl hydroperoxide to perform these oxidations. ${ }^{30}$ We have recently reported the use of cobalt(II), copper(II), manganese(II) and vanadium(II) catalysts in heterogeneous forms for the allylic oxidation 
of unsaturated steroids. ${ }^{31}$ Jurado-Gonzalez et al.$^{32}$ reported the allylic and benzylic oxidations using tert-butyl hydroperoxide and catalytic amounts of cobalt(II) alkyl phosphonate modified silica.

The increasing concern about environment and the need for green reagents have prompted research on the use of bismuth compounds as catalysts combined with tert-butyl hydroperoxide for allylic ${ }^{33}$ and benzylic ${ }^{34}$ oxidation reactions.

The development of metal-free ecofriendly synthetic transformations is an area of current interest. ${ }^{35}$ These methods avoid the use of toxic and expensive metals and seem to be especially attractive for the preparation of compounds that do not tolerate metal contamination, such as pharmaceutical products. The use of oxygen in the presence of $\mathrm{N}$-hydroxyphthalimide (NHPI) and an organic free-radical initiator $^{36}$ such as dibenzoyl peroxide, ${ }^{37}$ acetaldehyde, ${ }^{38}$ $\alpha, \alpha^{\prime}$-azobisisobutyronitrile, ${ }^{39}$ anthraquinones ${ }^{40}$ and acridine yellow $/ \mathrm{Br}_{2}{ }^{41}$ has been reported to be suitable for these oxidations. Recently, a procedure using sodium hypochlorite (household laundry bleach) in combination with aqueous tert-butyl hydroperoxide (70\% or less) has also been reported to perform allylic and benzylic oxidations. ${ }^{42}$

Sodium chlorite is a very cheap oxidant and has been extensively used in water treatment and as a bleaching agent in paper and textile industries. ${ }^{43}$ In the field of synthetic organic chemistry, the most known use of sodium chlorite is in the efficient chemoselective oxidation of aldehydes to the corresponding carboxylic acids. ${ }^{44}$ More recently increasing attention has been focused on its use in organic synthesis, for example, in the oxidation of primary alcohols ${ }^{45}$ and epoxidation of olefins. ${ }^{46}$

In this work, ${ }^{47}$ we report the use of sodium chlorite either in combination with tert-butyl hydroperoxide, in stoichiometric conditions, or with $N$-hydroxyphthalimide as catalyst for mild, transition-metal free, allylic and benzylic oxidation reactions.

\section{Results and discussion}

\subsection{Allylic and benzylic oxidations mediated by $\mathrm{NaClO}_{2} /$ tert-butyl hydroperoxide}

The recent growing interest in the use of sodium chlorite as a cheap oxidizing agent in organic chemistry motivated us to study its utility in allylic and benzylic oxidation reactions.

Firstly, we explored its use in combination with tert-butyl hydroperoxide and this association revealed to be practical and useful to accomplish the referred oxidations under mild conditions. Thus, using this system it was possible to effectively perform the transition-metal free allylic oxidation of $\Delta^{5}$-steroids 1-4 and (+)-valencene $\mathbf{5}$ and the benzylic oxidation of substrates 11-13 (Schemes 1 and 2 and Tables 1 and 2). In general, the reactions required 1.2 equiv of $\mathrm{NaClO}_{2}$ and 5 equiv of tert-butyl hydroperoxide, relative to the substrate, and could be performed using a homogeneous solvent mixture of $\mathrm{CH}_{3} \mathrm{CN}$ and water, at $50{ }^{\circ} \mathrm{C}$.
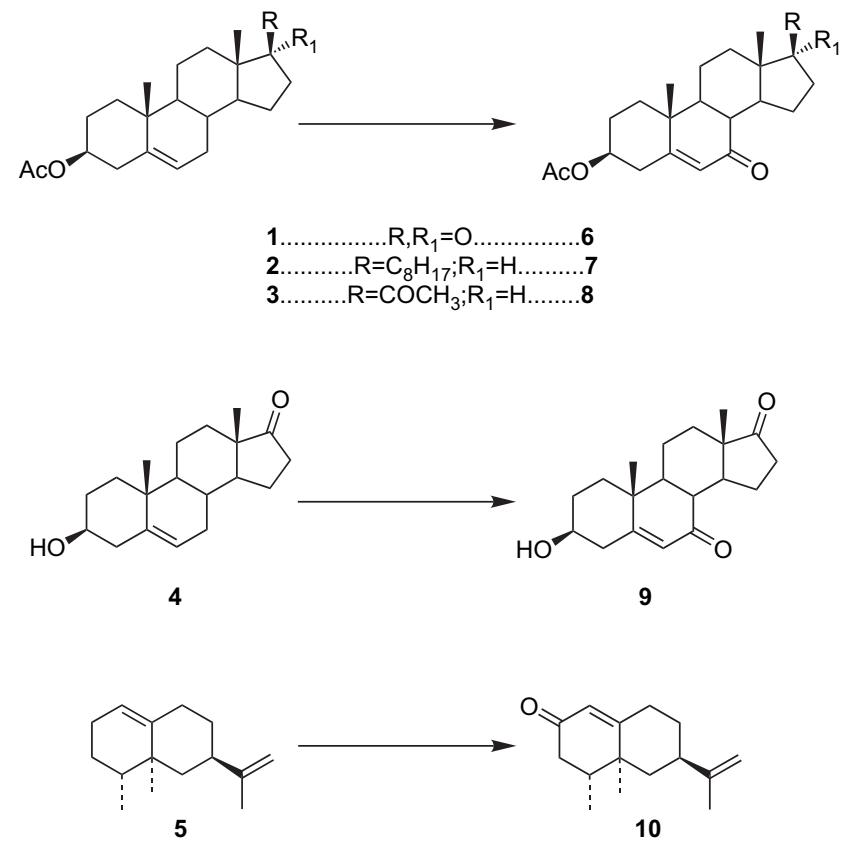

Scheme 1.
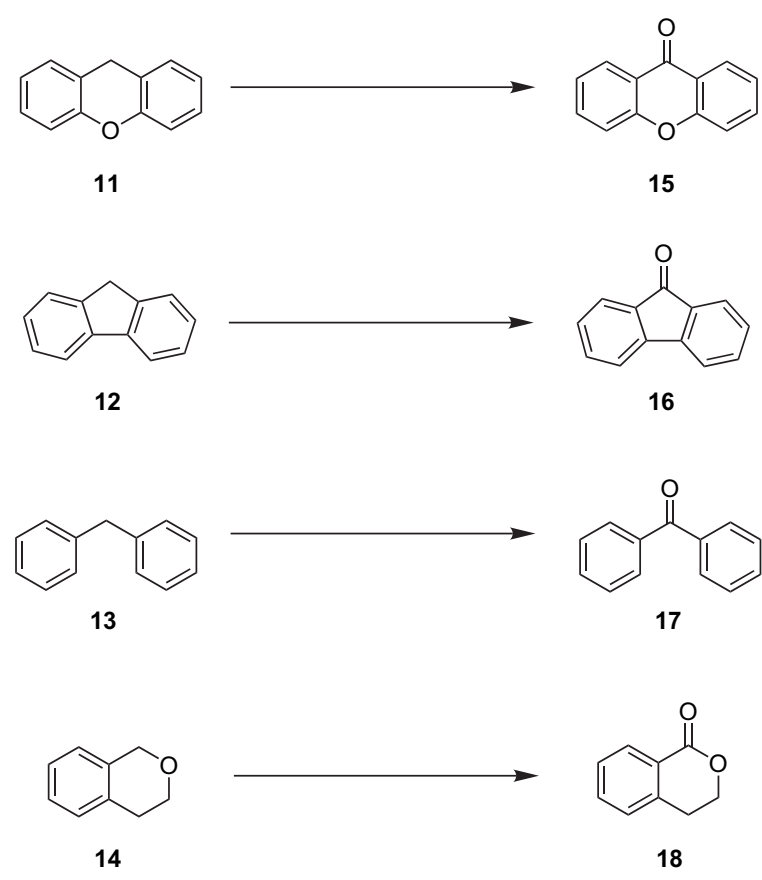

Scheme 2

In a first set of experiments, dehydroepiandrosterone acetate 1 was used as a model substrate under various experimental conditions. Blank experiments revealed that $\mathrm{NaClO}_{2}$ or tertbutyl hydroperoxide as the sole oxidant led only to traces of products after $50 \mathrm{~h}$ of reaction. Among the screened solvents, the best results were obtained with mixtures of $\mathrm{CH}_{3} \mathrm{CN}$ and water or with ethyl acetate (Table 1, entries 2-4 and 6). Using $\mathrm{CH}_{3} \mathrm{CN}$ or $1,4-$ dioxane/ $\mathrm{H}_{2} \mathrm{O}(3: 1, \mathrm{v} / \mathrm{v})$ as solvent, longer reaction times were observed (Table 1 , entries 1 and 5). Decreasing the amount of tert-butyl hydroperoxide to 1 equiv (per mmol of substrate) led to a longer reaction time (Table 1, entry 7). Reaction temperature was found to be a critical parameter. At $25^{\circ} \mathrm{C}$ the relative rate 
Table 1. Allylic oxidation of dehydroepiandrosterone acetate $\mathbf{1}$ by $\mathrm{NaClO}_{2} / t-\mathrm{BuOOH}$

\begin{tabular}{lllllllll}
\hline Entry & Substrate $/ \mathrm{mmol}^{2}$ & $\mathrm{NaClO}_{2}{ }^{\mathrm{a}} / \mathrm{mmol}$ & $t$ - $\mathrm{BuOOH}^{\mathrm{b}} / \mathrm{mmol}$ & $\mathrm{Solvent}(\mathrm{v} / \mathrm{v})$ & $\mathrm{Temp} /{ }^{\circ} \mathrm{C}$ & Time/h & Product & Isolated yield $/ \%$ \\
\hline 1 & $\mathbf{1} / 0.5$ & 0.6 & 2.5 & $\mathrm{CH}_{3} \mathrm{CN}$ & 50 & 44 & $\mathbf{6}$ & 77 \\
2 & $\mathbf{1} / 0.25$ & 0.3 & 1.25 & $\mathrm{CH}_{3} \mathrm{CN} / \mathrm{H}_{2} \mathrm{O}(3: 1)$ & 50 & 18 & $\mathbf{6}$ & 75 \\
3 & $\mathbf{1} / 0.25$ & 0.3 & 1.25 & $\mathrm{CH}_{3} \mathrm{CN} / \mathrm{H}_{2} \mathrm{O}(2: 1)$ & 50 & 20 & $\mathbf{6}$ & 79 \\
4 & $\mathbf{1} / 0.5$ & 0.6 & 2.5 & $\mathrm{CH}_{3} \mathrm{CN} / \mathrm{H}_{2} \mathrm{O}(1: 1)$ & 50 & 23 & $\mathbf{6}$ & 73 \\
5 & $\mathbf{1} / 0.25$ & 0.3 & 1.25 & $1,4-\mathrm{Dioxane} / \mathrm{H}_{2} \mathrm{O}(3: 1)$ & 50 & 72 & $\mathbf{6}$ & 79 \\
6 & $\mathbf{1} / 0.25$ & 0.3 & 1.25 & Ethyl acetate & 50 & 24 & $\mathbf{6}$ & 81 \\
7 & $\mathbf{1} / 0.5$ & 0.6 & 0.5 & $\mathrm{CH}_{3} \mathrm{CN} / \mathrm{H}_{2} \mathrm{O}(3: 1)$ & 50 & 96 & $\mathbf{6}$ & 74 \\
8 & $\mathbf{1} / 0.25$ & 0.5 & 1.25 & $\mathrm{CH}_{3} \mathrm{CN} / \mathrm{H}_{2} \mathrm{O}(3: 1)$ & 25 & 168 & $\mathbf{6}$ & 72 \\
9 & $\mathbf{1} / 0.25$ & 0.3 & 1.25 & $\mathrm{CH}_{3} \mathrm{CN}_{2} \mathrm{H}_{2} \mathrm{O}^{\mathrm{c}}(3: 1)$ & 50 & 24 & $\mathbf{6}$ & 72 \\
\hline
\end{tabular}

${ }^{a}$ Solid, $80 \%$ (Aldrich).

b Aqueous solution, $70 \%$ (Aldrich).

${ }^{c}$ EDTA aqueous solution $\left(5 \times 10^{-4} \mathrm{M}\right)$.

${ }^{\mathrm{d}}$ Traces of starting material and a by-product are visible on TLC plates but not detectable in ${ }^{1} \mathrm{H}$ NMR spectrum ( $\left.300 \mathrm{MHz}\right)$.

Table 2. Allylic and benzylic oxidations by $\mathrm{NaClO}_{2} / t-\mathrm{BuOOH}$

\begin{tabular}{|c|c|c|c|c|c|c|c|c|}
\hline Entry & Substrate/mmol & $\mathrm{NaClO}_{2}{ }^{\mathrm{a}} / \mathrm{mmol}$ & $t-\mathrm{BuOOH}^{\mathrm{b}} / \mathrm{mmol}$ & Solvent $(v / v)$ & $\mathrm{Temp} /{ }^{\circ} \mathrm{C}$ & Time/h & Product & Isolated yield $/ \%$ \\
\hline 1 & $2 / 0.5$ & 0.6 & 5 & $\mathrm{CH}_{3} \mathrm{CN}$ & 60 & 80 & 7 & $66^{\mathrm{d}}$ \\
\hline 2 & $3 / 0.25$ & 0.3 & 1.25 & $\mathrm{CH}_{3} \mathrm{CN} / \mathrm{H}_{2} \mathrm{O}(3: 1)$ & 50 & 28 & 8 & 76 \\
\hline 3 & $4 / 1$ & 1.2 & 5 & $\mathrm{CH}_{3} \mathrm{CN} / \mathrm{H}_{2} \mathrm{O}(2: 1)$ & 50 & 20 & 9 & $65^{\mathrm{d}}$ \\
\hline 4 & $5 / 1$ & 1.2 & 5 & $\mathrm{CH}_{3} \mathrm{CN} / \mathrm{H}_{2} \mathrm{O}(3: 1)$ & 50 & 22 & 10 & $38^{\mathrm{d}}$ \\
\hline 5 & $1 / 6$ & 7.2 & 30 & $\mathrm{CH}_{3} \mathrm{CN} / \mathrm{H}_{2} \mathrm{O}(3: 1)$ & 50 & 26 & 6 & 76 \\
\hline 6 & $11 / 0.5$ & 0.6 & 2.5 & $\mathrm{CH}_{3} \mathrm{CN} / \mathrm{H}_{2} \mathrm{O}(3: 1)$ & 50 & 40 & 15 & 89 \\
\hline 7 & $12 / 0.5$ & 0.6 & 2.5 & $\mathrm{CH}_{3} \mathrm{CN} / \mathrm{H}_{2} \mathrm{O}(3: 1)$ & 50 & 64 & 16 & 90 \\
\hline 8 & $13 / 0.5$ & 0.6 & 2.5 & $\mathrm{CH}_{3} \mathrm{CN} / \mathrm{H}_{2} \mathrm{O}(3: 1)$ & 50 & 52 & 17 & 86 \\
\hline
\end{tabular}

${ }^{\text {a }}$ Solid, $80 \%$ (Aldrich).

b Aqueous solution, $70 \%$ (Aldrich).

${ }^{c}$ Traces of starting material and a by-product are visible on TLC plates but not detectable in ${ }^{1} \mathrm{H}$ NMR spectrum $(300 \mathrm{MHz})$.

${ }^{d}$ Recovered by flash chromatography (ethyl acetate/light petroleum, bp $40-60{ }^{\circ} \mathrm{C}$ ).

of conversion was very slow (Table 1, entry 8 ) in comparison to the reactions performed at $50{ }^{\circ} \mathrm{C}$ and therefore we considered the use of this temperature for the study of the process. In the presence of ethylenediamine tetraacetic acid (EDTA), a metal ion sequestering agent, no significant changes were seen in the reaction indicating that this allylic oxidation was not being catalyzed by the presence of adventitious metal ions in the solvent (Table 1, entry 9).

Due to solubility reasons, the oxidation of substrate $\mathbf{2}$ was performed using $\mathrm{CH}_{3} \mathrm{CN}$ as the solvent and the 7-ketone derivative 7 was obtained in good yield (Table 2, entry 1). When applied to substrate $\mathbf{3}$, this new oxidative system afforded product 8 in $76 \%$ yield (Table 2, entry 2 ).

The chemoselective allylic oxidation in the presence of a secondary hydroxyl group was studied using dehydroepiandrosterone $\mathbf{4}$ as the substrate and the corresponding 7-ketone derivative 9 was obtained with good chemoselectivity $(65 \%$ isolated yield) (Table 2, entry 3 ). A similar oxidation was performed on (+)-valencene $\mathbf{5}$ under these conditions and the sesquiterpenoid nootkatone $\mathbf{1 0}$ was the major reaction product (38\% yield) (Table 2, entry 4). In agreement with these results, when performed on a larger scale, only a small decrease in the reaction rate was observed (Table 2, entry 5).

In spite of longer reaction times, benzylic compounds, xanthene 11, fluorene 12 and diphenylmethane 13 were oxidized to the corresponding benzylic ketones, xanthone 15, fluorenone 16 and benzophenone 17 (Scheme 2) in high yields (Table 2, entries 6-8).
The mechanism of these oxidation reactions is worth considering. An experiment was conducted under the same reaction conditions (Section 4.2; Table 1, entry 2) but in the presence of a radical inhibitor, butylated hydroxy toluene (BHT, $20 \mathrm{~mol} \%$ ), and it was observed that the oxidation was inhibited until BHT was consumed. This information implied that this process occurred via freeradical species.

Recently, Geng et al. demonstrated the formation of chlorine dioxide radical $\left(\mathrm{ClO}_{2}\right)$ by heating $\mathrm{NaClO}_{2}$ at $55-65{ }^{\circ} \mathrm{C}$ in $\mathrm{CH}_{3} \mathrm{CN} / \mathrm{H}_{2} \mathrm{O}(4: 1){ }^{46}$ As our conditions are similar, we also considered the formation of that compound. Thus, the mixture of $\mathrm{NaClO}_{2}(1.2 \mathrm{mmol})$ in $\mathrm{CH}_{3} \mathrm{CN} / \mathrm{H}_{2} \mathrm{O}$ (3:1) $(12 \mathrm{~mL})$ was heated at $50{ }^{\circ} \mathrm{C}$ during $15 \mathrm{~h}$, and the UV spectrum of the resulting cooled solution showed the characteristic absorption peak of $\mathrm{ClO}_{2}\left(\lambda_{\max }=359 \mathrm{~nm}\right),{ }^{43,46}$ in agreement with the previously reported results. ${ }^{46}$ Furthermore, the presence of $\mathrm{ClO}_{2}$ radical was confirmed by Electron Spin Resonance (ESR) experiments. ${ }^{48}$

As this reaction was not catalyzed by metal ions (Table 1 , entry 9) and did not occur using only $\mathrm{NaClO}_{2}$ or tert-butyl hydroperoxide (blank experiments), the process was most likely initiated by the homolytic cleavage of tert-butyl hydroperoxide by $\mathrm{ClO}_{2}$ radicals, originating tert-butylperoxy radical. This reactive intermediate initiates the allylic (and benzylic) hydrogen abstraction leading to the formation of the olefin radical, which is further oxidized via a radical chain mechanism to the corresponding enone. ${ }^{42 b}$ 


\subsection{Allylic and benzylic oxidations mediated by $\mathrm{NaClO}_{2}$, catalyzed by $\mathrm{N}$-hydroxyphthalimide (NHPI)}

Due to the interesting results obtained with the system $\mathrm{NaClO}_{2} /$ tert-butyl hydroperoxide, we decided to study the use of $\mathrm{NaClO}_{2}$ as the sole oxidant in a catalytic process. Knowing the fact that chlorine dioxide is a reasonable disproportionate product of $\mathrm{NaClO}_{2}$ when heated and an inherent radical species itself, ${ }^{46}$ although not enough active to perform allylic oxidation, we considered the possible association of $\mathrm{NaClO}_{2}$ with a radical catalyst such as NHPI as an effective oxidizing system. Actually, this combination resulted in a powerful transition-metal free catalytic oxidative system for these allylic and benzylic oxidations. Thus, the allylic oxidation of $\Delta^{5}$-steroids $\mathbf{1 - 4}$ and (+)-valencene 5 and the benzylic oxidation of substrates 11-14 (Schemes 1 and 2 and Tables 3 and 4) have been readily performed under mild conditions.

In general, the reactions were very fast and required 1.5 equiv of $\mathrm{NaClO}_{2}$ and 0.1 equiv of NHPI, relative to the substrate, and could be performed using a homogeneous solvent mixture of $\mathrm{CH}_{3} \mathrm{CN}$ and water, at $50{ }^{\circ} \mathrm{C}$.

The catalyst NHPI in the absence of $\mathrm{NaClO}_{2}$ was not active, as revealed by the blank experiments.

The best solvent for this system was the mixture of $\mathrm{CH}_{3} \mathrm{CN}$ and water (usually $2: 1$ or $3: 1, \mathrm{v} / \mathrm{v}$ ) (Table 3 , entries 1 and 2), however, dioxane $/ \mathrm{H}_{2} \mathrm{O}(3: 1$, v/v) could also be used, although a longer reaction time has been observed (Table 3 , entry 3). The use of $N$-hydroxysuccinimide (NHSI) in place of NHPI led to an increase in the reaction time and lower yield (Table 3, entry 4). 2,2,6,6-Tetramethylpiperidine1-oxyl (TEMPO) has no catalytic activity under these conditions (Table 3, entry 5). The reduction of the amount of NHPI to 0.05 equiv led to a significant reduction in the reaction rate (Table 3 , entry 6). The study of the effect of temperature in this reaction allowed us to observe that significantly shortened times were required at $50{ }^{\circ} \mathrm{C}$ (Table 3, entries 2 and 7) and for this reason we studied the process using this temperature.

The presence of EDTA in the reaction system did not change the results significantly, indicating that this reaction occurs without the influence of traces of metal ions in the solvent (Table 3, entry 8). This reaction is also not influenced by the molecular oxygen present in air, as the results were not changed when the reaction was performed under nitrogen atmosphere (Table 3, entry 9).

The use of $\mathrm{NaOCl}$ ( $5 \%$ aqueous solution; household laundry bleach) instead of $\mathrm{NaClO}_{2}$ within the same reaction conditions led to some reactivity, however, low selectivity was observed.

When applied to substrates $\mathbf{2}$ and $\mathbf{3}$, this new oxidative system afforded products $\mathbf{7}$ and $\mathbf{8}$ in 60 and $76 \%$ yields, respectively (Table 4 , entries 1 and 2).

The reaction of dehydroepiandrosterone 4 led to the corresponding 7-ketone derivative $\mathbf{9}$ in moderate yield. The

Table 3. Allylic oxidation of dehydroepiandrosterone acetate $\mathbf{1}$ by $\mathrm{NaClO}_{2} /$ organic catalyst

\begin{tabular}{|c|c|c|c|c|c|c|c|c|}
\hline Entry & Substrate/mmol & $\mathrm{NaClO}_{2}{ }^{\mathrm{a}} / \mathrm{mmol}$ & Catalyst/mmol & Solvent $(\mathrm{v} / \mathrm{v})$ & $\mathrm{Temp} /{ }^{\circ} \mathrm{C}$ & Time/h & Product & Isolated yield $\mathrm{d} / \%$ \\
\hline 1 & $\mathbf{1} / 0.25$ & 0.375 & NHPI/0.025 & $\mathrm{CH}_{3} \mathrm{CN} / \mathrm{H}_{2} \mathrm{O}(2: 1)$ & 50 & 6 & 6 & 89 \\
\hline 2 & $\mathbf{1} / 0.25$ & 0.375 & NHPI/0.025 & $\mathrm{CH}_{3} \mathrm{CN} / \mathrm{H}_{2} \mathrm{O}(3: 1)$ & 50 & 6 & 6 & 75 \\
\hline 3 & $1 / 0.25$ & 0.375 & NHPI/0.025 & 1,4-Dioxane $/ \mathrm{H}_{2} \mathrm{O}(3: 1)$ & 50 & 14 & 6 & 84 \\
\hline 4 & $\mathbf{1} / 0.25$ & 0.375 & NHSI/0.025 & $\mathrm{CH}_{3} \mathrm{CN} / \mathrm{H}_{2} \mathrm{O}(2: 1)$ & 50 & 8 & 6 & 72 \\
\hline 5 & $\mathbf{1} / 0.25$ & 0.375 & TEMPO/0.025 & $\mathrm{CH}_{3} \mathrm{CN} / \mathrm{H}_{2} \mathrm{O}(2: 1)$ & 50 & 40 & - & - \\
\hline 6 & $\mathbf{1} / 0.25$ & 0.375 & NHPI/0.0125 & $\mathrm{CH}_{3} \mathrm{CN} / \mathrm{H}_{2} \mathrm{O}(2: 1)$ & 50 & 24 & 6 & 76 \\
\hline 7 & $1 / 0.25$ & 0.375 & NHPI/0.025 & $\mathrm{CH}_{3} \mathrm{CN} / \mathrm{H}_{2} \mathrm{O}(3: 1)$ & 25 & 144 & 6 & 78 \\
\hline 8 & $\mathbf{1} / 0.25$ & 0.375 & NHPI/0.025 & $\mathrm{CH}_{3} \mathrm{CN} / \mathrm{H}_{2} \mathrm{O}^{\mathrm{b}}(2: 1)$ & 50 & 7 & 6 & 77 \\
\hline 9 & $1 / 0.25$ & 0.375 & NHPI/0.025 & $\mathrm{CH}_{3} \mathrm{CN} / \mathrm{H}_{2} \mathrm{O}^{\mathrm{c}}(2: 1)$ & 50 & 6 & 6 & 82 \\
\hline
\end{tabular}

${ }^{a}$ Solid, $80 \%$ (Aldrich).

b EDTA aqueous solution $\left(5 \times 10^{-4} \mathrm{M}\right)$.

${ }^{c}$ Performed under $\mathrm{N}_{2}$ atmosphere.

${ }^{\mathrm{d}}$ Traces of starting material and a by-product are visible on TLC plates but not detectable in ${ }^{1} \mathrm{H}$ NMR spectrum (300 MHz).

Table 4. Allylic and benzylic oxidations by $\mathrm{NaClO}_{2} / \mathrm{NHPI}$

\begin{tabular}{|c|c|c|c|c|c|c|c|c|}
\hline Entry & Substrate/mmol & $\mathrm{NaClO}_{2}{ }^{\mathrm{a}} / \mathrm{mmol}$ & $\mathrm{NHPI} / \mathrm{mmol}$ & Solvent (v/v) & $\mathrm{Temp} /{ }^{\circ} \mathrm{C}$ & Time/h & Product & Isolated yield $/ \%$ \\
\hline 1 & $2 / 0.5$ & 1.5 & 0.05 & 1,4-Dioxane $/ \mathrm{H}_{2} \mathrm{O}(3: 1)$ & 50 & 25 & 7 & $60^{\mathrm{c}}$ \\
\hline 2 & $3 / 0.25$ & 0.375 & 0.025 & $\mathrm{CH}_{3} \mathrm{CN} / \mathrm{H}_{2} \mathrm{O}(3: 1)$ & 50 & 7 & 8 & 76 \\
\hline 3 & $4 / 1$ & 1.5 & 0.1 & $\mathrm{CH}_{3} \mathrm{CN} / \mathrm{H}_{2} \mathrm{O}(2: 1)$ & 50 & 11 & 9 & $50^{\mathrm{c}}$ \\
\hline 4 & $5 / 1$ & 1.5 & 0.1 & $\mathrm{CH}_{3} \mathrm{CN} / \mathrm{H}_{2} \mathrm{O}(3: 1)$ & 50 & 15 & 10 & $36^{\mathrm{c}}$ \\
\hline 5 & $1 / 3$ & 4.5 & 0.3 & $\mathrm{CH}_{3} \mathrm{CN} / \mathrm{H}_{2} \mathrm{O}(2: 1)$ & 50 & 8 & 6 & 76 \\
\hline 6 & $11 / 0.5$ & 0.75 & 0.05 & $\mathrm{CH}_{3} \mathrm{CN} / \mathrm{H}_{2} \mathrm{O}(3: 1)$ & 50 & 2 & 15 & 91 \\
\hline 7 & $12 / 0.5$ & 0.75 & 0.05 & $\mathrm{CH}_{3} \mathrm{CN} / \mathrm{H}_{2} \mathrm{O}(3: 1)$ & 50 & 1 & 16 & 90 \\
\hline 8 & $13 / 0.5$ & 0.75 & 0.05 & $\mathrm{CH}_{3} \mathrm{CN} / \mathrm{H}_{2} \mathrm{O}(3: 1)$ & 50 & 6 & 17 & 89 \\
\hline 9 & $14 / 0.5$ & 0.75 & 0.05 & $\mathrm{CH}_{3} \mathrm{CN} / \mathrm{H}_{2} \mathrm{O}(3: 1)$ & 50 & 18 & 18 & 75 \\
\hline
\end{tabular}

\footnotetext{
a Solid, $80 \%$ (Aldrich).

b Traces of starting material and a by-product are visible on TLC plates but not detectable in ${ }^{1} \mathrm{H}$ NMR spectrum $(300 \mathrm{MHz})$.

${ }^{c}$ Recovered by flash chromatography (ethyl acetate/light petroleum, bp $40-60{ }^{\circ} \mathrm{C}$ ).
} 
higher reactivity of this system is probably the reason for the moderate chemoselectivity observed in the oxidation of this substrate (Table 4, entry 3).

The sesquiterpenoid nootkatone $\mathbf{1 0}$ was the major product (36\% yield) of the allylic oxidation of (+)-valencene 5 under these conditions (Table 4, entry 4). When performed on a larger scale using dehydroepiandrosterone $\mathbf{1}$ as substrate, this procedure allowed the obtention of product $\mathbf{6}$ in $76 \%$ yield and with only a small decrease in the reaction rate (Table 4, entry 5).

When applied to benzylic substrates such as xanthene 11, fluorene 12 and diphenylmethane $\mathbf{1 3}$ this procedure allowed excellent results. Thus, the corresponding benzylic ketones, xanthone 15, fluorenone 16 and benzophenone 17 (Scheme 2 ) were obtained in very high yields and within short reaction times (Table 4, entries 6-8). The benzylic oxidation of isochromane $\mathbf{1 4}$ led to 1 -isochromanone $\mathbf{1 8}$ in $75 \%$ yield (Table 4, entry 9).

When performed under the same reaction conditions (Section 4.3; Table 3, entry 1), but in the presence of BHT (20 mol \%), this process was inhibited until the radical inhibitor consumption, which indicates that these oxidations were also mediated by free-radical species.

It is known that NHPI is a radical catalyst, mediating various oxidation reactions by $\mathrm{O}_{2}$ via the formation of the phthalimide $N$-oxyl (PINO) radical intermediate. ${ }^{49}$ This catalyst is commonly associated with metallic or organic free-radical initiators to perform oxidation reactions using $\mathrm{O}_{2}$ as the oxidant. $^{49}$

We demonstrated that this reaction was not catalyzed by metal ions (Table 3, entry 8) and did not occur using only $\mathrm{NaClO}_{2}$ or NHPI catalyst (blank experiments). In addition, we confirmed by UV and ESR experiments that $\mathrm{ClO}_{2}$ was generated by heating $\mathrm{NaClO}_{2}$ at $50{ }^{\circ} \mathrm{C}$. ESR studies of the mixture of $\mathrm{NaClO}_{2}(0.375 \mathrm{mmol})$ and NHPI $(0.025 \mathrm{mmol})$ in $\mathrm{CH}_{3} \mathrm{CN} / \mathrm{H}_{2} \mathrm{O}(2: 1)(3 \mathrm{~mL})$ at room temperature revealed the simultaneous presence of $\mathrm{ClO}_{2}{ }^{48}$ and PINO. ${ }^{50}$

Therefore, considering these observations, we propose that under these reaction conditions, $\mathrm{NaClO}_{2}$ originated $\mathrm{ClO}_{2}$ radicals, which should react with NHPI leading to the formation of PINO radical. This reactive intermediate can abstract allylic (and benzylic) hydrogens ${ }^{49}$ originating the olefin radical, which is in turn oxidized via a radical chain mechanism to the corresponding enone. ${ }^{49}$

\section{Conclusions}

In summary, allylic and benzylic oxidation reactions can be cheaply and effectively performed using sodium chlorite either in combination with tert-butyl hydroperoxide in stoichiometric conditions, or with $N$-hydroxyphthalimide as catalyst under mild, transition-metal free conditions. These very simple, economical and ecofriendly procedures led to good yields and selectivities and, therefore, should find a large use in organic synthesis.

\section{Experimental}

\subsection{General}

Substrates 1-4, 12-14, $\mathrm{NaClO}_{2}, t$-BuOOH, NHPI, NHSI, TEMPO and BHT were commercially available from Sigma-Aldrich Co. (+)-Valencene $\mathbf{5}$ and xanthene 11 were purchased from Fluka. Reaction solvents were distilled before use, according to standard procedures. Kieselgel $60 \mathrm{HF}_{254} /$ Kieselgel $60 \mathrm{G}$ was used for TLC analysis. Melting points were determined with a Reichert microscope apparatus and were uncorrected. IR spectral analyses were performed in a JASCO FT/IR-420 spectrophotometer. ${ }^{1} \mathrm{H}$ and ${ }^{13} \mathrm{C}$ NMR spectra were recorded on a Bruker AMX 300 spectrometer, in $\mathrm{CDCl}_{3}$ solution with $\mathrm{Me}_{4} \mathrm{Si}$ as internal standard. UV spectral analyses were performed in a Bausch \& Lomb Spectronic 2000 spectrophotometer. ESR measurements were carried out on a Bruker EMX 1144 spectrometer (X-band) with a $100 \mathrm{kHz}$ field modulation.

\subsection{General procedure for allylic and benzylic oxida- tions mediated by $\mathrm{NaClO}_{2} /$ tert-butyl hydroperoxide}

In a typical reaction, to a solution of the substrate (e.g., 17-oxoandrost-5-en-3 $\beta$-yl acetate $1,82.6 \mathrm{mg} / 0.25 \mathrm{mmol}$ ) in $\mathrm{CH}_{3} \mathrm{CN} / \mathrm{H}_{2} \mathrm{O}(3: 1, \mathrm{v} / \mathrm{v})(3 \mathrm{~mL})$, tert-butyl hydroperoxide ( $0.18 \mathrm{~mL} / 1.25 \mathrm{mmol}, 70 \%$ aqueous solution, Aldrich) was added followed by the slow addition of $\mathrm{NaClO}_{2}$ (33.92 mg/0.3 mmol, 80\%, Aldrich). After $18 \mathrm{~h}$ under magnetic stirring at $50{ }^{\circ} \mathrm{C}$, the reaction was complete (TLC control). The reaction mixture was poured into sodium sulfite solution (10\% aqueous) and extracted with diethyl ether. The extract was washed with aqueous saturated solution of $\mathrm{NaHCO}_{3}$, water, dried and evaporated to dryness to give 7,17-dioxoandrost-5-en-3 $\beta$-yl acetate $\mathbf{6}(62.6 \mathrm{mg}$, $75 \%$ yield). Crystallization from methanol afforded $67 \%$ of pure product; mp $180-183{ }^{\circ} \mathrm{C}(\mathrm{MeOH})$; lit. ${ }^{51} 184{ }^{\circ} \mathrm{C}$; IR (ATR): 1244, 1627, 1671, 1721, 1738, 2922, $3020 \mathrm{~cm}^{-1}$; ${ }^{1} \mathrm{H} \mathrm{NMR}\left(\mathrm{CDCl}_{3}, 300 \mathrm{MHz}\right): \delta 0.89\left(\mathrm{~s}, 3 \mathrm{H}, 18-\mathrm{CH}_{3}\right), 1.24$ $\left(\mathrm{s}, 3 \mathrm{H}, 19-\mathrm{CH}_{3}\right), 2.06\left(\mathrm{~s}, 3 \mathrm{H}, \mathrm{CH}_{3} \mathrm{CO}\right), 4.72(\mathrm{~m}, 1 \mathrm{H}$, $3 \alpha-\mathrm{CH}), 5.76(\mathrm{~m}, 1 \mathrm{H}, 6-\mathrm{CH}) ;{ }^{13} \mathrm{C} \mathrm{NMR}\left(\mathrm{CDCl}_{3}, 75 \mathrm{MHz}\right)$ : $\delta 71.90$ (C-3), 126.43 (C-6), 164.79 (C-5), 170.19 $\left(\mathrm{CH}_{3} \mathrm{CO}\right), 200.66$ (C-7), 220.14 (C-17).

\subsection{General procedure for allylic and benzylic oxidations mediated by $\mathrm{NaClO}_{2}$, catalyzed by NHPI}

In a typical reaction, to a solution of the substrate (e.g., 17-oxoandrost-5-en-3 $\beta$-yl acetate $1,82.6 \mathrm{mg} / 0.25 \mathrm{mmol}$ ) in $\mathrm{CH}_{3} \mathrm{CN} / \mathrm{H}_{2} \mathrm{O}(2: 1, \quad \mathrm{v} / \mathrm{v})(3 \mathrm{~mL})$, NHPI $(4.1 \mathrm{mg} /$ $0.025 \mathrm{mmol}, 97 \%$, Aldrich) was added, followed by the slow addition of $\mathrm{NaClO}_{2} \quad(42.4 \mathrm{mg} / 0.375 \mathrm{mmol}, 80 \%$, Aldrich). After $6 \mathrm{~h}$ under magnetic stirring at $50{ }^{\circ} \mathrm{C}$, the reaction was complete (TLC control). The reaction mixture was poured into sodium sulfite solution (10\% aqueous) and extracted with diethyl ether. The extract was washed with aqueous saturated solution of $\mathrm{NaHCO}_{3}$, water, dried and evaporated to dryness to give 7,17-dioxoandrost-5-en$3 \beta$-yl acetate $\mathbf{6}(76.6 \mathrm{mg}, 89 \%$ yield). Crystallization from methanol afforded $78 \%$ of pure product.

4.3.1. Compound 7. $\mathrm{Mp} 155-157^{\circ} \mathrm{C}(\mathrm{MeOH})$; lit. $^{52} 158-$ $159{ }^{\circ} \mathrm{C}$; IR (ATR): 1244, 1628, 1670, 1727, 2950, 
$3025 \mathrm{~cm}^{-1} ;{ }^{1} \mathrm{H}$ NMR $\left(\mathrm{CDCl}_{3}, 300 \mathrm{MHz}\right): \delta 0.68(\mathrm{~s}, 3 \mathrm{H}$, $\left.18-\mathrm{CH}_{3}\right), 0.86\left(\mathrm{~d}, J=6.6 \mathrm{~Hz}, 6 \mathrm{H}, 26-\mathrm{CH}_{3}, 27-\mathrm{CH}_{3}\right), 0.92$ $\left(\mathrm{d}, J=6.5 \mathrm{~Hz}, 3 \mathrm{H}, 21-\mathrm{CH}_{3}\right), 1.20\left(\mathrm{~s}, 3 \mathrm{H}, 19-\mathrm{CH}_{3}\right), 2.03$ (s, $\left.3 \mathrm{H}, \mathrm{CH}_{3} \mathrm{CO}\right), 4.69(\mathrm{~m}, 1 \mathrm{H}, 3 \alpha-\mathrm{CH}), 5.70(\mathrm{~m}, 1 \mathrm{H}, 6-\mathrm{CH})$; ${ }^{13} \mathrm{C}$ NMR $\left(\mathrm{CDCl}_{3}, 75 \mathrm{MHz}\right): \delta 72.17$ (C-3), 126.64 (C-6), 163.82 (C-5), $170.22\left(\mathrm{CH}_{3} \mathrm{CO}\right), 201.87(\mathrm{C}-7)$.

4.3.2. Compound 8. $\mathrm{Mp} 150-153{ }^{\circ} \mathrm{C}(\mathrm{MeOH}) ;$ lit. $^{53} 152-$ $153^{\circ} \mathrm{C}$; IR (ATR): 1244, 1630, 1669, 1704, 1727, 2941, $3037 \mathrm{~cm}^{-1} ;{ }^{1} \mathrm{H}$ NMR $\left(\mathrm{CDCl}_{3}, 300 \mathrm{MHz}\right): \delta 0.66(\mathrm{~s}, 3 \mathrm{H}$, $\left.18-\mathrm{CH}_{3}\right), 1.21\left(\mathrm{~s}, 3 \mathrm{H}, 19-\mathrm{CH}_{3}\right), 2.06\left(\mathrm{~s}, 3 \mathrm{H}, \mathrm{CH}_{3} \mathrm{CO}\right), 2.14$ $\left(\mathrm{s}, 3 \mathrm{H}, 21-\mathrm{CH}_{3}\right), 4.72(\mathrm{~m}, 1 \mathrm{H}, 3 \alpha-\mathrm{CH}), 5.73(\mathrm{~m}, 1 \mathrm{H}, 6-$ $\mathrm{CH}) ;{ }^{13} \mathrm{C}$ NMR $\left(\mathrm{CDCl}_{3}, 75 \mathrm{MHz}\right): \delta 72.00(\mathrm{C}-3), 126.41$ (C-6), 164.13 (C-5), $170.23\left(\mathrm{CH}_{3} \mathrm{CO}\right), 201.11$ (C-7), $209.64(\mathrm{C}-20)$.

4.3.3. Compound 9. $\mathrm{Mp} 229-232{ }^{\circ} \mathrm{C}(\mathrm{MeOH}) ;$ lit. $^{53} 232.5-$ $233^{\circ} \mathrm{C}$; IR (ATR): 1298, 1630, 1649, 1719, 2941, 3025, $3480 \mathrm{~cm}^{-1} ;{ }^{1} \mathrm{H}$ NMR $\left(\mathrm{CDCl}_{3}, 300 \mathrm{MHz}\right): \delta 0.90(\mathrm{~s}, 3 \mathrm{H}$, $\left.18-\mathrm{CH}_{3}\right), 1.23\left(\mathrm{~s}, 3 \mathrm{H}, 19-\mathrm{CH}_{3}\right), 3.68(\mathrm{~m}, 1 \mathrm{H}, 3 \alpha-\mathrm{CH}), 5.75$ $(\mathrm{m}, 1 \mathrm{H}, 6-\mathrm{CH}) ;{ }^{13} \mathrm{C} \mathrm{NMR}\left(\mathrm{CDCl}_{3}, 75 \mathrm{MHz}\right): \delta 70.2(\mathrm{C}-3)$, 125.7 (C-6), 166.2 (C-5), 200.7 (C-7), 219.8 (C-17).

4.3.4. Compound 10. Mp $31-34{ }^{\circ} \mathrm{C}$; lit. ${ }^{54} 33-35{ }^{\circ} \mathrm{C}$; IR (ATR): 1617, 1663, 2933, 3029, $3079 \mathrm{~cm}^{-1} ;{ }^{1} \mathrm{H}$ NMR $\left(\mathrm{CDCl}_{3}, 300 \mathrm{MHz}\right): \delta 0.94\left(\mathrm{~d}, J=6.8 \mathrm{~Hz}, 3 \mathrm{H}, 15-\mathrm{CH}_{3}\right)$, $1.09\left(\mathrm{~s}, 3 \mathrm{H}, 14-\mathrm{CH}_{3}\right), 1.71\left(\mathrm{~s}, 3 \mathrm{H}, 13-\mathrm{CH}_{3}\right), 4.70(\mathrm{~m}, 2 \mathrm{H}$, $\left.12-\mathrm{CH}_{2}\right), 5.74(\mathrm{~s}, 1 \mathrm{H}, 1-\mathrm{CH}) ;{ }^{13} \mathrm{C} \mathrm{NMR}\left(\mathrm{CDCl}_{3}, 75 \mathrm{MHz}\right)$ : $\delta 109.12$ (C-12), 124.44 (C-1), 148.87 (C-11), 170.82 (C-10), 199.79 (C-2).

4.3.5. Compound 15. Mp $169-171^{\circ} \mathrm{C}(\mathrm{PhH})$; lit. ${ }^{55} 172-$ $173{ }^{\circ} \mathrm{C}$; IR (ATR): 757, 1145, 1345, 1456, 1479, 1605, 1655, 2937, $3079 \mathrm{~cm}^{-1} ;{ }^{1} \mathrm{H}$ NMR $\left(\mathrm{CDCl}_{3}, 300 \mathrm{MHz}\right)$ : $\delta 7.38(\mathrm{t}, J=7.9 \mathrm{~Hz}, 2 \mathrm{H}, 2-\mathrm{CH}, 7-\mathrm{CH}), 7.49(\mathrm{~d}, J=8.4 \mathrm{~Hz}$, $2 \mathrm{H}, 4-\mathrm{CH}, 5-\mathrm{CH}), 7.73(\mathrm{~m}, 2 \mathrm{H}, 3-\mathrm{CH}, 6-\mathrm{CH}), 8.34(\mathrm{dd}$, $J=7.9,1.7 \mathrm{~Hz}, 2 \mathrm{H}, 1-\mathrm{CH}, 8-\mathrm{CH}) ;{ }^{13} \mathrm{C} \mathrm{NMR}\left(\mathrm{CDCl}_{3}\right.$, $75 \mathrm{MHz}$ ): $\delta \quad 117.95$ (C-4, C-5), 121.81 (C-8a, C-9a), 123.87 (C-2, C-7), 126.70 (C-1, C-8), 134.78 (C-3, C-6), 156.14 (C-4a, C-10a), 177.19 (C-9).

4.3.6. Compound 16. $\mathrm{Mp} 79-82{ }^{\circ} \mathrm{C}(\mathrm{MeOH})$; lit. ${ }^{55} 81-$ $82{ }^{\circ} \mathrm{C}$; IR (ATR): $1297,1449,1598,1712,3060 \mathrm{~cm}^{-1} ;{ }^{1} \mathrm{H}$ NMR $\left(\mathrm{CDCl}_{3}, 300 \mathrm{MHz}\right): \delta 7.28(\mathrm{~m}, 2 \mathrm{H}, 2-\mathrm{CH}, 7-\mathrm{CH})$, $7.48(\mathrm{~m}, 4 \mathrm{H}, 3-\mathrm{CH}, 4-\mathrm{CH}, 5-\mathrm{CH}, 6-\mathrm{CH}), 7.65$ (d, $J=7.4 \mathrm{~Hz}, 2 \mathrm{H}, 1-\mathrm{CH}, 8-\mathrm{CH}) ;{ }^{13} \mathrm{C} \mathrm{NMR}\left(\mathrm{CDCl}_{3}, 75 \mathrm{MHz}\right)$ : $\delta 120.27$ (C-4, C-5), 124.27 (C-1, C-8), 129.03 (C-2, C-7), 134.09 (C-8a, C-9a), 134.65 (C-3, C-6), 144.38 (C-4a, C-4b), 193.89 (C-9).

4.3.7. Compound 17. $\mathrm{Mp} 46-47.5^{\circ} \mathrm{C}(\mathrm{MeOH})$; lit. ${ }^{56} 47-$ $49^{\circ} \mathrm{C}$; IR (ATR): 810, 1276, 1447, 1594, 1650, $3057 \mathrm{~cm}^{-1}$; ${ }^{1} \mathrm{H} \mathrm{NMR}\left(\mathrm{CDCl}_{3}, 300 \mathrm{MHz}\right): \delta 7.46(\mathrm{~m}, 4 \mathrm{H}$, 4-CH, 6-CH, 10-CH, 12-CH), 7.57 (m, 2H, 5- $\mathrm{CH}, 11-\mathrm{CH})$, 7.80, (m, 4H, 3-CH, 7-CH, 9-CH, $13-\mathrm{CH}) ;{ }^{13} \mathrm{C}$ NMR $\left(\mathrm{CDCl}_{3}, 75 \mathrm{MHz}\right): \delta 128.19$ (C-4, C-6, C-10, C-12), 129.96 (C-3, C-7, C-9, C-13), 132.34 (C-5, C-11), 137.48 (C-2, C-8), 196.66 (C-1).

4.3.8. Compound 18. Colourless oil ${ }^{57}$ IR (film): 695,747 , 1092, 1121, 1244, 1295, 1394, 1459, 1607, 1721, 2951, $3070 \mathrm{~cm}^{-1} ;{ }^{1} \mathrm{H}$ NMR $\left(\mathrm{CDCl}_{3}, 300 \mathrm{MHz}\right): \delta 3.05(\mathrm{t}$, $\left.J=6 \mathrm{~Hz}, 2 \mathrm{H}, 4-\mathrm{CH}_{2}\right), 4.53\left(\mathrm{t}, J=6 \mathrm{~Hz}, 2 \mathrm{H}, 3-\mathrm{CH}_{2}\right), 7.27$ (d, $J=7.6 \mathrm{~Hz}, 1 \mathrm{H}, 5-\mathrm{CH}), 7.39(\mathrm{t}, J=7.5 \mathrm{~Hz}, 1 \mathrm{H}, 7-\mathrm{CH})$, $7.54(\mathrm{~m}, 1 \mathrm{H}, 6-\mathrm{CH}), 8.08(\mathrm{~d}, J=7.7 \mathrm{~Hz}, 1 \mathrm{H}, 8-\mathrm{CH}) ;{ }^{13} \mathrm{C}$ NMR $\left(\mathrm{CDCl}_{3}, 75 \mathrm{MHz}\right): \delta 27.64$ (C-4), 67.19 (C-3), $125.11,127.14,127.52,130.18,133.55,139.44$ (arom.), $165.02(\mathrm{C}-1)$.

\section{Acknowledgements}

J.A.R.S. thanks Universidade de Coimbra for financial support. S.M.S. thanks Fundação para a Ciência e Tecnologia for a grant (SFRH/BD/11087/2002). We kindly acknowledge the Center of NMR Spectroscopy and Center for Neurosciences and Cell Biology, University of Coimbra, Portugal (Professor C. Geraldes) and Professor J. Laranjinha (Center for Neurosciences and Cell Biology, University of Coimbra, Portugal) for the ESR experiments.

\section{References and notes}

1. (a) Muzart, J. Bull. Soc. Chim. Fr. 1986, 65; (b) Bulman Page, P. C.; McCarthy, T. J. Comprehensive Organic Synthesis; Trost, B. M., Flemming, I., Eds.; Pergamon: Oxford, New York, NY, Seoul, Tokyo, 1991; Vol. 7, pp 83-117; (c) Sheldon, R. A.; Kochi, J. K. Metal-Catalyzed Oxidations of Organic Compounds; Academic: New York, NY, London, Toronto, Sydney, San Francisco, CA, 1981.

2. Arsenou, E. S.; Fousteris, M. A.; Koutsourea, A. I.; Nikolaropoulos, S. S. Mini Rev. Med. Chem. 2003, 3, 557.

3. Sousa, M. E.; Pinto, M. M. M. Curr. Med. Chem. 2005, 12, 2447.

4. (a) Dauben, W. G.; Lorber, M.; Fullerton, D. S. J. Org. Chem. 1969, 34, 3587; (b) Fullerton, D. S.; Chen, C.-M. Synth. Commun. 1976, 6, 217.

5. Salmond, W. G.; Barta, M. A.; Havens, J. L. J. Org. Chem. 1978, 43, 2057.

6. Parish, E. J.; Chitrakorn, S.; Wei, T.-Y. Synth. Commun. 1986, $16,1371$.

7. Parish, E. J.; Wei, T.-Y. Synth. Commun. 1987, 17, 1227.

8. Chidambaram, N.; Chandrasekaran, S. J. Org. Chem. 1987, 52, 5048.

9. Marshall, C. W.; Ray, R. E.; Laos, I.; Riegel, B. J. Am. Chem. Soc. 1957, 79, 6308.

10. Amann, A.; Ourisson, G.; Luu, B. Synthesis 1987, 1002.

11. Parish, E. J.; Sun, H.; Kizito, S. A. J. Chem. Res., Synop. 1996, 544.

12. Bora, U.; Chaudhuri, M. K.; Dey, D.; Kalita, D.; Kharmawphlang, W.; Mandal, G. C. Tetrahedron 2001, 57, 2445.

13. Marwah, P.; Lardy, H. A. U.S. Patent 6,384,251 B1, 2002.

14. Hudlický, M. Oxidations in Organic Chemistry; ACS Monograph 186; American Chemical Society: Washington, DC, 1990 and references cited therein.

15. (a) Bennur, T. H.; Sabne, S.; Deshpande, S. S.; Srinivas, D.; Sivasanker, S. J. Mol. Catal. A: Chem. 2002, 185, 71; (b) Klopstra, M.; Hage, R.; Kellogg, R. M.; Feringa, B. L. Tetrahedron Lett. 2003, 44, 4581; (c) Maksimchuk, N. V.; Melgunov, M. S.; Mrowiec-Białoń, J.; Jarzębski, A. B.; Kholdeeva, O. A. J. Catal. 2005, 235, 175.

16. Punniyamurthy, T.; Velusamy, S.; Iqbal, J. Chem. Rev. 2005, 105, 2329 and references cited therein.

17. Salvador, J. A. R.; Silvestre, S. M.; Moreira, V. M. Curr. Org. Chem. 2006, 10, 2227. 
18. (a) Muzart, J. Tetrahedron Lett. 1987, 28, 4665; (b) Muzart, J. Tetrahedron Lett. 1987, 28, 2131.

19. Muzart, J. Tetrahedron Lett. 1986, 27, 3139.

20. Fousteris, M. A.; Koutsourea, A. I.; Nikolaropoulos, S. S.; Riahi, A.; Muzart, J. J. Mol. Catal. A: Chem. 2006, 250, 70.

21. (a) Pearson, A. J.; Chen, Y.-S.; Hsu, S.-Y.; Ray, T. Tetrahedron Lett. 1984, 25, 1235; (b) Pearson, A. J.; Chen, Y.-S.; Han, G. R.; Hsu, S.-Y.; Ray, T. J. Chem. Soc., Perkin Trans. 1 1985, 267; (c) Pearson, A. J.; Han, G. R. J. Org. Chem. 1985, 50, 2791.

22. (a) Murahashi, S.-I.; Oda, Y.; Naota, T.; Kuwabara, T. Tetrahedron Lett. 1993, 34, 1299; (b) Murahashi, S.-I.; Komiya, N.; Oda, Y.; Kuwabara, T.; Naota, T. J. Org. Chem. 2000, 65, 9186.

23. (a) Miller, R. A.; Thompson, A. S.; Bakshi, R. K.; Corley, E. G. WO Patent 95/32215, 1995; (b) Miller, R. A.; Li, W.; Humphrey, G. R. Tetrahedron Lett. 1996, 37, 3429.

24. (a) Salvador, J. A. R.; Sá e Melo, M. L.; Campos Neves, A. S. Tetrahedron Lett. 1997, 38, 119; (b) Salvador, J. A. R.; Sá e Melo, M. L. C. F. V.; Campos Neves, A. S. U.S. Patent 6,252,119 B1, 2001; (c) Rothenberg, G.; Feldberg, L.; Wiener, H.; Sasson, Y. J. Chem. Soc., Perkin Trans. 2 1998, 2429.

25. (a) Salvador, J. A. R.; Clark, J. H. Chem. Commun. 2001, 33; (b) Clark, J. H.; Salvador, J. A. R. WO Patent 02/16391, 2002.

26. (a) Catino, A. J.; Forslund, R. E.; Doyle, M. P. J. Am. Chem. Soc. 2004, 126, 13622; (b) Catino, A. J.; Nichols, J. M.; Choi, H.; Gottipamula, S.; Doyle, M. P. Org. Lett. 2005, 7, 5167.

27. Pan, J.-F.; Chen, K. J. Mol. Catal. A: Chem. 2001, 176, 19.

28. Shing, T. K. M.; Yeung, Y.-Y.; Su, P. L. Org. Lett. 2006, 8, 3149.

29. Clark, J. H.; Macquarrie, D. J. Handbook of Green Chemistry and Technology; Blackwell Science: Oxford, 2002.

30. (a) Choudary, B. M.; Prasad, A. D.; Swapna, V.; Valli, V. L. K.; Bhuma, V. Tetrahedron 1992, 48, 953; (b) Choudary, B. M.; Prasad, A. D.; Bhuma, V.; Swapna, V. J. Org. Chem. 1992, 57, 5841; (c) Lempers, H. E. B.; Sheldon, R. A. Appl. Catal. A: Gen. 1996, 143, 137; (d) Dapurkar, S. E.; Sakthivel, A.; Selvam, P. New J. Chem. 2003, 27, 1184; (e) Lounis, Z.; Riahi, A.; Djafri, F.; Muzart, J. Appl. Catal. A: Gen. 2006, 309, 270.

31. Salvador, J. A. R.; Clark, J. H. Green Chem. 2002, 4, 352.

32. Jurado-Gonzalez, M.; Sullivan, A. C.; Wilson, J. R. H. Tetrahedron Lett. 2003, 44, 4283.

33. (a) Salvador, J. A. R.; Silvestre, S. M. Tetrahedron Lett. 2005, 46, 2581; (b) Salvador, J. A. R.; Silvestre, S. M. PT Patent 103,211, 2006.

34. Bonvin, Y.; Callens, E.; Larrosa, I.; Henderson, D. A.; Oldham, J.; Burton, A. J.; Barrett, A. G. M. Org. Lett. 2005, 7, 4549.

35. Adam, W.; Saha-Möller, C. R.; Ganeshpure, P. A. Chem. Rev. 2001, 101, 3499.

36. Various hydroaromatic and benzylic compounds can be oxidized under a normal pressure of $\mathrm{O}_{2}$, catalyzed by NHPI $(10 \mathrm{~mol} \%)$, even in the absence of transition-metal species or organic free-radical initiators, however, reactions were generally performed in benzonitrile at $100{ }^{\circ} \mathrm{C}$ : Ishii, Y.; Nakayama, K.; Takeno, M.; Sakaguchi, S.; Iwahama, T.; Nishiyama, Y. J. Org. Chem. 1995, 60, 3934.

37. Foricher, J.; Fürbringer, C.; Pfoertner, K. U.S. Patent 5,030,739, 1991.

38. Einhorn, C.; Einhorn, J.; Marcadal, C.; Pierre, J.-L. Chem. Commun. 1997, 447.

39. (a) Aoki, Y.; Sakaguchi, S.; Ishii, Y. Adv. Synth. Catal. 2004, 346, 199; (b) Coutts, L. D.; DeOrazio, R. J.; Meckler, H. Synth. Commun. 2005, 35, 979.

40. Yang, G.; Zhang, Q.; Miao, H.; Tong, X.; Xu, J. Org. Lett. 2005, 7, 263.

41. Tong, X.; Xu, J.; Miao, H.; Gao, J. Tetrahedron Lett. 2006, 47, 1763.

42. (a) Marwah, P.; Lardy, H. A.; Marwah, A. K. U.S. Patent 6,274,746 B1, 2001; (b) Marwah, P.; Marwah, A.; Lardy, H. A. Green Chem. 2004, 6, 570.

43. Fábián, I. Coord. Chem. Rev. 2001, 216-217, 449 and references cited therein.

44. Krapcho, A. P. Org. Prep. Proced. Int. 2006, 38, 177 and references cited therein.

45. (a) Zhao, M.; Li, J.; Mano, E.; Song, Z.; Tschaen, D. M.; Grabowski, E. J. J.; Reider, P. J. J. Org. Chem. 1999, 64, 2564; (b) Devine, P. N.; Mano, E.; Song, Z.; Tschaen, D. M.; Zhao, M. U.S. Patent 6,031,101, 2000.

46. Geng, X.-L.; Wang, Z.; Li, X.-Q.; Zhang, C. J. Org. Chem. 2005, 70, 9610 .

47. Salvador, J. A. R.; Silvestre, S. M. PT Patent Appl. 103,592, 2006.

48. ESR spectra were obtained under the following conditions: frequency $9.7 \mathrm{GHz}$, modulation amplitude $2 \mathrm{G}$ and microwave power $20 \mathrm{~mW}$. The characteristic quartet signal is in agreement with the spectrum attributed to $\mathrm{ClO}_{2}$ radical: Ozawa, T.; Miura, Y.; Ueda, J.-I. Free Radical Biol. Med. 1996, 20, 837.

49. (a) Ishii, Y.; Sakaguchi, S.; Iwahama, T. Adv. Synth. Catal. 2001, 343, 393; (b) Sheldon, R. A.; Arends, I. W. C. E. Adv. Synth. Catal. 2004, 346, 1051.

50. ESR spectra were obtained under the conditions reported in Ref. 48. The characteristic triplet signal is in agreement with the spectrum attributed to PINO: Ishii, Y.; Iwahama, T.; Sakaguchi, S.; Nakayama, K.; Nishiyama, Y. J. Org. Chem. 1996, 61, 4520.

51. Billeter, J. R.; Miescher, K. Helv. Chim. Acta 1948, 31, 629.

52. Buser, W. Helv. Chim. Acta 1947, 30, 1379.

53. Logemann, W.; Giraldi, P. Gazz. Chim. Ital. 1951, 81, 548.

54. Arantes, S. F.; Farooq, A.; Hanson, J. R. J. Chem. Res., Miniprint 1999, 801.

55. Shaabani, A.; Mirzaei, P.; Naderi, S.; Lee, D. G. Tetrahedron 2004, 60, 11415.

56. Shaabani, A.; Soleimani, K.; Bazgir, A. Synth. Commun. 2004, 34, 3303.

57. Ochiai, M.; Ito, T.; Takahashi, H.; Nakanishi, A.; Toyonari, T.; Sueda, T.; Goto, S.; Shiro, M. J. Am. Chem. Soc. 1996, 118, 7716. 